\title{
FLOOD RELATED DISASTERS: CONCERNED TO URBAN FLOODING IN BANGALORE, INDIA
}

\author{
Shubha Avinash ${ }^{1}$ \\ ${ }^{\text {I}}$ Project Scientist, Karnataka State Natural Disaster Monitoring Center, Bangalore, Karnataka
}

\begin{abstract}
Flood is one of the significant and frequent disasters in the world. Of these more than $50 \%$ of the events occur in Asia. Every year there is loss of human life, animals, houses, goods and property due to the outrage of floods. Urban areas are witnessing drastic population growth resulting in decreasing rainwater infiltration and increase in runoff and flood peak. Severe and frequent flooding events are possibly due to climate change, socio-economic damage, migration, development practices and political instability, which constantly reshape flood vulnerability. As a part of an integrated urban flood studies at KSNDMC, we are developing a plan for "Urban storm water flood management"-for Bangalore city, which is often subjected to monsoon fury.

This paper describes the causes, circumstances and impact of flooding events in Bangalore city. In an urban scenario, like Bangalore, floods occur due to natural phenomenon such as heavy and / or high intensity rainfall, human factors such as blocking of storm water drains, population growth leading to improper land use \& unplanned settlements etc. The immediate impact of floods will be mainly on the public transportation because of water submerging the roads, urban settlements in low laying areas due to inundation, chocking of storm water drains inundating the surrounding houses. In the Developing countries, like India, the activities of Flood management are handled by government and are still adopting a reactive approach during floods. This should be changed to proactive action which enhance effectiveness of management and reduce losses. For planning and implementing an effective short and long term flood management plan participation and co-operation between Government, non-governmental, private agencies and public is a prerequisite.
\end{abstract}

Keywords: flood vulnerability, socio-economic damage, migration, development practices and political instability.

\section{INTRODUCTION}

Flood is a significant and recurring disaster. Repeated floods lead to loss of human life, animal life, property and assets. Many factors, natural and human activities is responsible for flooding in the urban scenario. Urban flood is a highlighted issue of disaster management which needs a first order priority focusing on the assessment of flood vulnerable areas, Flood hazardous mapping, mitigation plans and flood early warnings and forecasting. This will help in proper decision making towards mitigating and management of floods.

Bangalore with a geographical area of almost $800 \mathrm{SqKm}$, is located almost equidistance forms both the eastern and western coast of south Indian peninsula. The Mean annual rainfall is about $975 \mathrm{~mm}$ with about 59 rainy days a year. It has 12.591 North latitude \& 77.571East longitude. It has an altitude of $920 \mathrm{~m}$ above sea level. Bangalore is the fifth largest city of India with population of about 9.6 million, located around $100 \mathrm{~km}$ from the Kaveri River. There has been a growth of $32 \%$ in urban areas of Greater Bangalore across 37years (1973-2009).Encroachment of wetlands, floodplains, etc. is causing floodway obstruction and loss of natural flood storage in Bangalore. 
Table- 1 \& Graph-1 (Reference -1)

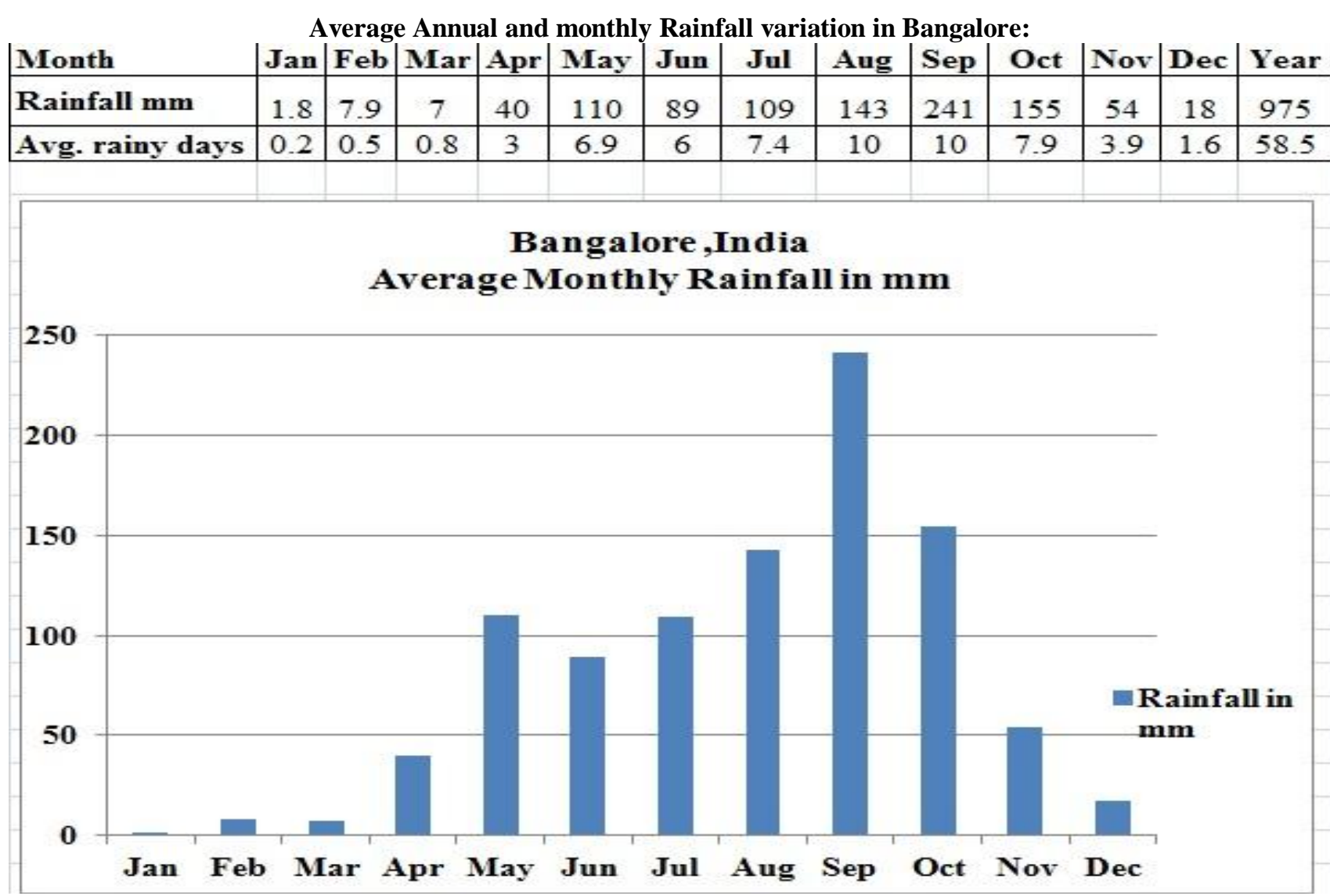

As in Table-1 and Graph- 1, according to IMD sources, wettest months of the year are September, October and August for Bangalore city.

\section{CAUSES FOR FLOODS IN BANGALORE:}

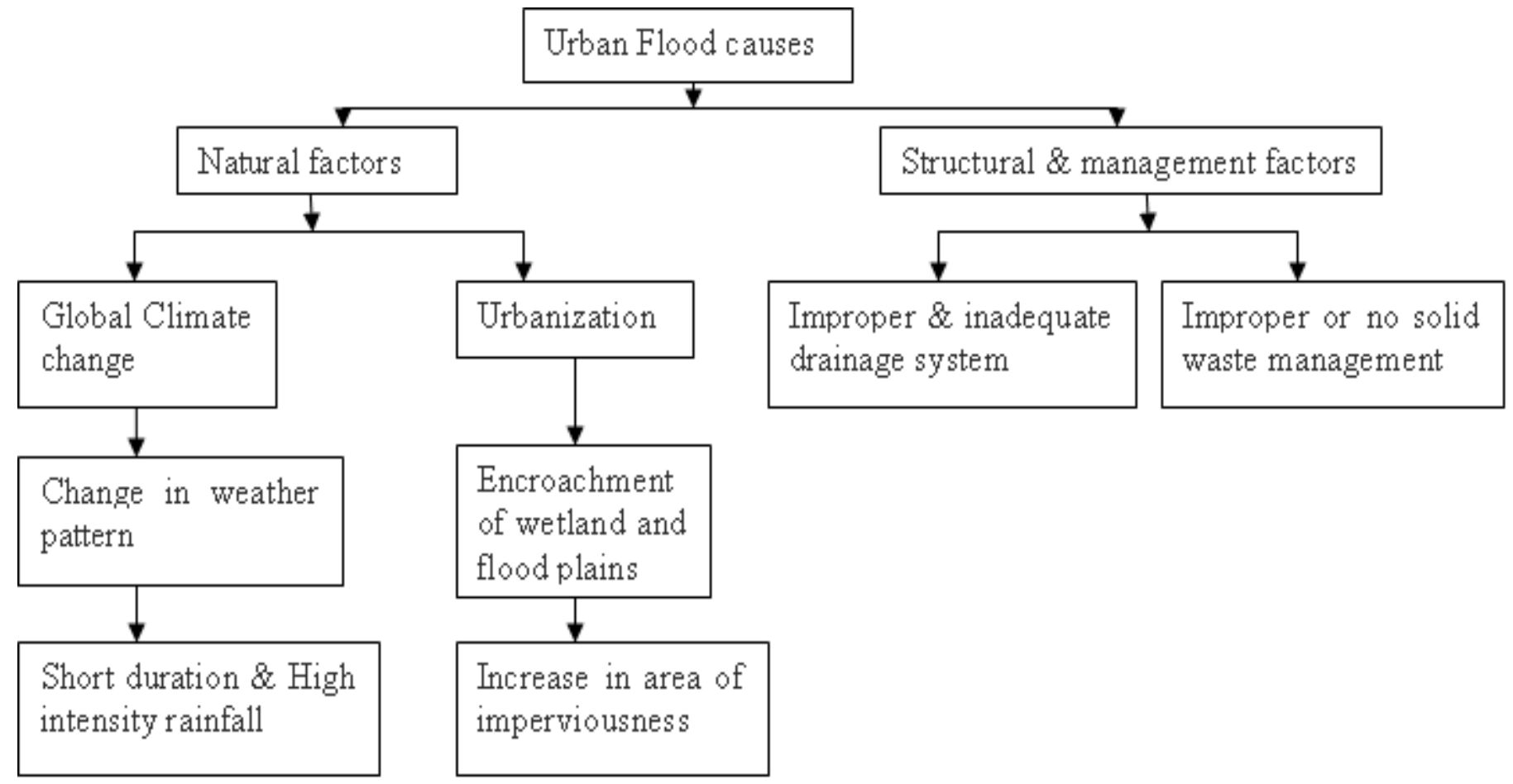


Urban floods happen in a relatively short period of time and can inundate an area with several feet of water. It is due to short duration and high intensity rainfall. As areas become 'urbanized' or go through the process of urbanization, there are increased flood risks. The main problem with urban flooding is the fact that they occur in highly populated areas. Although the property damages and death toll is not to the peak in urban flood scenario, it is very significant.

Urbanization leads to migration of people to urban areas for living. It directly leads to increase in population. The developments and utility services cannot cope up with the population growth, which directly impact on improper solid waste management system. The garbage disposal into the storm water drains choke the flow and the carrying capacity of the Storm water drain leading to over flooding of the drains during the high rain events.
As more wet lands, open spaces, tanks and wooded areas are converted to urban and suburban areas, the amount of surface area available for water infiltration into the soils decreases. Home sites, parking lots, buildings, and roadways all decrease the surface area of soil on Earth's surface. Because of the entire paved areas the imperviousness of the land increases with which water is redirected into sewage and storm water drainage systems.

\section{Circumstances and Impact of floods in Bangalore: High} rain event study in the year 2013:

Urban storm water flooding effects mainly the low laying areas in city. There are almost 147 low laying areas in the city as surveyed by Bruhath Bengaluru Mahanagara Palike (BBMP). Almost 130 low laying locations are been mapped in Arc GIS with Zone wise distribution as in Fig-1.

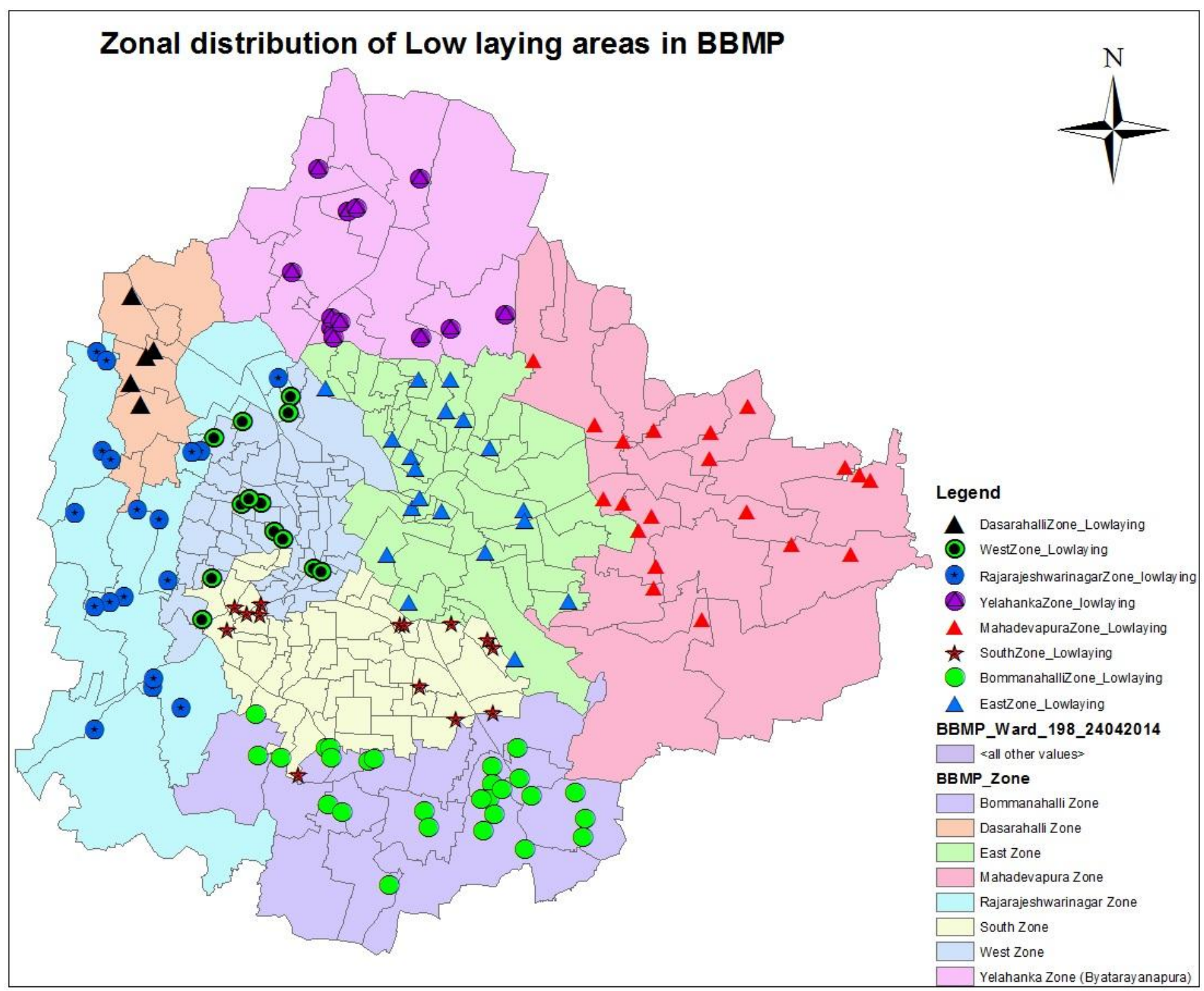

Fig-1 Zonal distribution of Low laying areas in Bangalore (Reference -2)

Bangalore has four major watersheds. Hebbal valley, Vrishabhavathi valley, Koramangala valley and Challagatta valley watershed. Part of Hesragatta valley watershed falls inside Bangalore BBMP area. These watershed delineation is made using Arc GIS as in Fig- 2. 


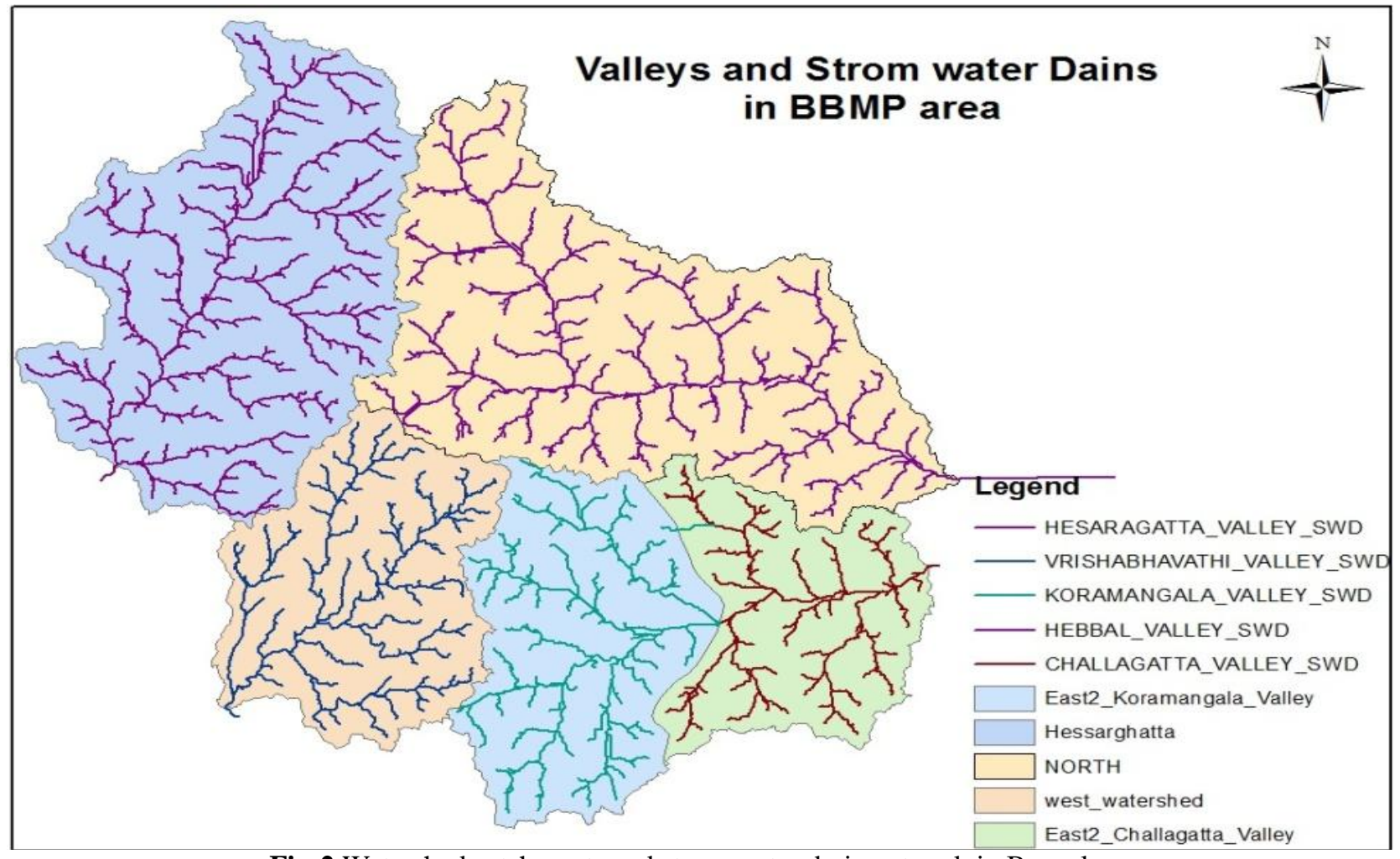

Fig-2 Watershed catchments and storm water drain network in Bangalore

The center has 100 solar powered GPRS enabled Telemetric Rain gauge network in BBMP area which has 198 wards and 8 zones as in Fig- 3

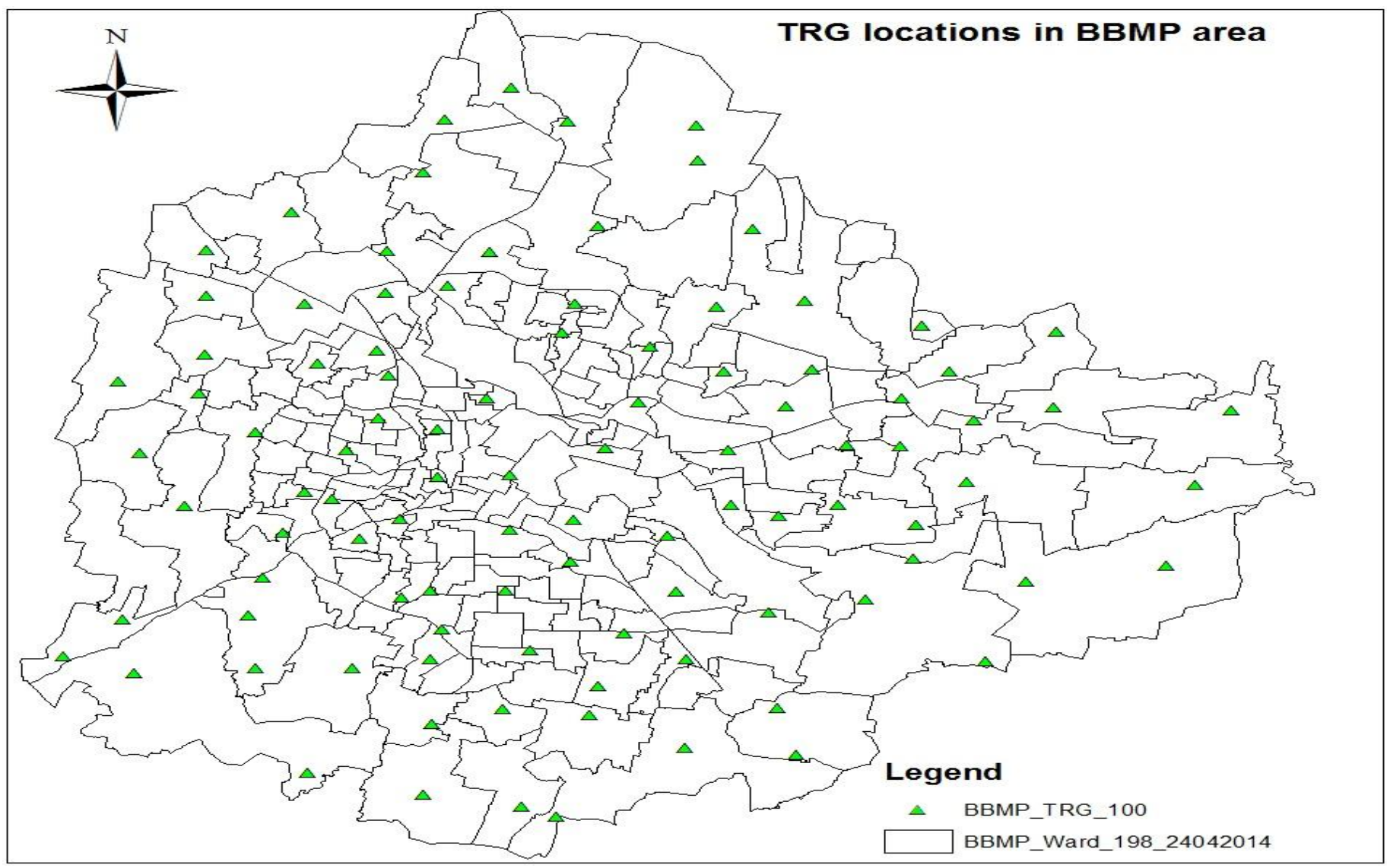

Fig-3 Watershed catchments and storm water drain network in Bangalore 
According to our study in the center, the high rain events suffered in Bangalore city in the year 2013 has affected in a very bad way. The residential units, transport path near to the drains are flooded resulting in disturbed living of the people/public.

\section{NOVEMBER $23^{\text {rd }} 2013$ RAIN EVENT:}

Rainfall Runoff calculation was done for November 23rd 2013 rain event for a particular low laying area in west zone. It was observed that the runoff generated was six times more than the carrying capacity of the drain. The following Table- 2 shows the calculations done to estimate the Runoff volume.

Table- 2 Runoff analysis for West zone low laying area for $23^{\text {rd }}$ November 2013 rains RUNOFF ANALYYSIS FOR WESTCORE LOWLAYING AREA-23rd NOVEMBER 2013 RAIN

\begin{tabular}{|c|c|c|c|c|c|c|c|c|c|c|c|c|c|c|c|c|c|}
\hline SL.NOF & FID grid & $\begin{array}{l}\text { AREA_GRID } \\
\text { (SQ-KM) }\end{array}$ & $\begin{array}{c}\text { Ward } \\
\text { No }\end{array}$ Ward Name & $\begin{array}{l}\text { FID T } \\
\text { heiss }\end{array}$ & $\begin{array}{l}\text { Area_S } \\
q \mathrm{~km}\end{array}$ & TRG & Rain(mm) & 1) Drain id & $\begin{array}{l}\text { CARRYING } \\
\text { CAPACITY(swd) }\end{array}$ & \begin{tabular}{|c|} 
AREA \\
WEIGHTED_AVERAG \\
EGRID \\
\end{tabular} & $\begin{array}{l}\text { WATERDEP } \\
\text { THIN } \\
\text { GRID(MM) }\end{array}$ & $\begin{array}{l}\text { VOLUME| } \\
\text { MB)GRID } \\
\end{array}$ & $\begin{array}{l}\text { \%IMPER } \\
\text { VIOUS }\end{array}$ & $\begin{array}{l}\text { RUNOFF } \\
\text { COEFFICIENT }\end{array}$ & $\begin{array}{l}\text { RUNOFF } \\
\text { VOLUME(M } \\
3)\end{array}$ & $\begin{array}{l}Q \\
\text { (M3) } \\
\text { SEC) }\end{array}$ & $\begin{array}{l}V \\
\text { M/S/S } \\
\text { EC) } \\
\end{array}$ \\
\hline 1 & 486 & 0.4 & 138 Chalavadipalya & 41 & & 2309 & & 4 V106 & 19186.57125 & 0.066666667 & 4.26666667 & \begin{tabular}{|l|}
1706.6667 \\
\end{tabular} & 96 & 0.91 & 1553.06667 & & \\
\hline 2 & 487 & 0.6 & 138 Chalavadipalya & 41 & & 2309 & & 4 V106 & 19186.57125 & 0.1 & 6.4 & 3840 & 98 & 0.93 & 3571.2 & & \\
\hline 3 & 519 & 0.3 & 122 Kempapura & 41 & & 2309 & & 4 V100,V106 & 120706.5338 & 0.05 & 3.2 & 960 & 99 & 0.94 & 902.4 & & \\
\hline 4 & 520 & 0.95 & 120 Cottonpete & 41 & & 2309 & & 44 V100,V107,V108 & 122325.0338 & 0.158333333 & 10.133333 & 9626.6667 & 95 & 0.9 & 8664 & & \\
\hline 5 & 521 & 0.45 & 94 Gandhi Nagar & 36 & & 2327 & 110.5 & & & 0.075 & 8.2875 & 3729.375 & 96 & 0.91 & 3393.73125 & & \\
\hline 6 & 522 & 0.1 & 94 Gandhi Nagar & 36 & & 2327 & 110.5 & & & 0.016666667 & 1.84166667 & 184.16667 & 95 & 0.9 & 165.75 & & \\
\hline 7 & 553 & 0.35 & 108 Sri Ramamandir & 35 & & 2342 & & .5 V115 & 6643.21875 & 0.0875 & 5.73125 & 2005.9375 & 96 & 0.91 & 1825.40313 & & \\
\hline 8 & 554 & 1 & 108 Sri Ramamandir & 35 & & 2342 & & .5 V100,V112 & 134738.2125 & 0.25 & 16.375 & 16375 & 100 & 0.95 & 15556.25 & & \\
\hline 9 & 555 & 1 & 94 Gandhi Nagar & 35 & & 2342 & 65.5 & & & 0.25 & 16.375 & 16375 & 96 & 0.91 & 14901.25 & & \\
\hline 10 & 556 & 0.35 & 94 Gandhi Nagar & 35 & & 2342 & 65.5 & & & 0.0875 & 5.73125 & 2005.9375 & 98 & 0.93 & 1865.52188 & & \\
\hline 11 & 587 & 0.35 & 108 Sri Ramamandir & 42 & & 2306 & 42 & 12 & & 0.058333333 & 2.45 & 857.5 & 95 & 0.9 & 771.75 & & \\
\hline 12 & 588 & 1 & 96 Okalipuram & 35 & & 2342 & & 5 V112,V113,V114 & 37601.25 & 0.25 & 16.375 & 16375 & 93 & 0.88 & 14410 & & \\
\hline 13 & 589 & 1 & 95 Subhash Nagar & 35 & & 2342 & & .5 V100 & 101519.9625 & 0.25 & 16.375 & 16375 & 98 & 0.93 & 15228.75 & & \\
\hline 14 & 590 & 0.5 & 94 Gandhi Nagar & 35 & & 2342 & & 5 V110 & 588 & 0.125 & 8.1875 & 4093.75 & 97 & 0.92 & 3766.25 & & \\
\hline 15 & 621 & 0.6 & 99 Rajajijnagar & 42 & & 2306 & & 12 V112 & 33218.25 & 0.1 & 4.2 & 2520 & 94 & 0.89 & 2242.8 & & \\
\hline 16 & 622 & 0.95 & 98 Prakash Nagar & 35 & & 2342 & 65.5 & & & 0.2375 & 15.55625 & 14778.438 & 95 & 0.9 & 13300.5938 & & \\
\hline 17 & 623 & 0.75 & 65 Kadu Malleshwal & 35 & & 2342 & & 5 V100 & 101519.9625 & 0.1875 & 12.28125 & 9210.9375 & 97 & 0.92 & 8474,0625 & & \\
\hline 18 & 624 & 0.6 & 77 Dattatreya Temp & 40 & & 2310 & 121.5 & & & 0.066666667 & 8.1 & 4860 & 99 & 0.94 & 4568.4 & & \\
\hline 19 & 655 & 0.22 & 67 Nagapura & 82 & & 2300 & 45 & 15 & & 0.031428571 & 1.41428571 & 311.14286 & 97 & 0.92 & 286.251429 & & \\
\hline 20 & 656 & 0.2 & 45 Malleshwaram & 82 & & 2300 & 45 & 15 & & 0.028571429 & 1.28571429 & 257.14286 & 96 & 0.91 & 234 & & \\
\hline 21 & 657 & 0.35 & 35 Aramane Nagara & 40 & & 2310 & 121.5 & & & 0.038888889 & 4.725 & 1653.75 & 95 & 0.9 & 1488.375 & & \\
\hline \multirow[t]{2}{*}{22} & 658 & 0.35 & 35 Aramane Nagara & 40 & & 2310 & 121.5 & & & 0.038888889 & 4.725 & 1653.75 & 94 & 0.89 & 1471.8375 & & \\
\hline & & 12.47 & & & & & & & & & & 129755 & & & 118642 & & 4.4 \\
\hline
\end{tabular}

\begin{tabular}{|c|}
\hline AREA OF THE WATERSHED FOR WEST LOWLAYING $=12.47$ SQKM \\
\hline VOLUME OF WATER GENERATED IN THE WATERSHED DUE TO RAIN EVENT= 129755 CUBIC METER \\
\hline RUNOFF VOLUME IN THE WATERSHED = 118642 CUBUC METER \\
\hline AT POINT "A" : CARRYING CAPACITY OF THE ORAIN, V106 $=19186.57$ CUBIC METER \\
\hline
\end{tabular}




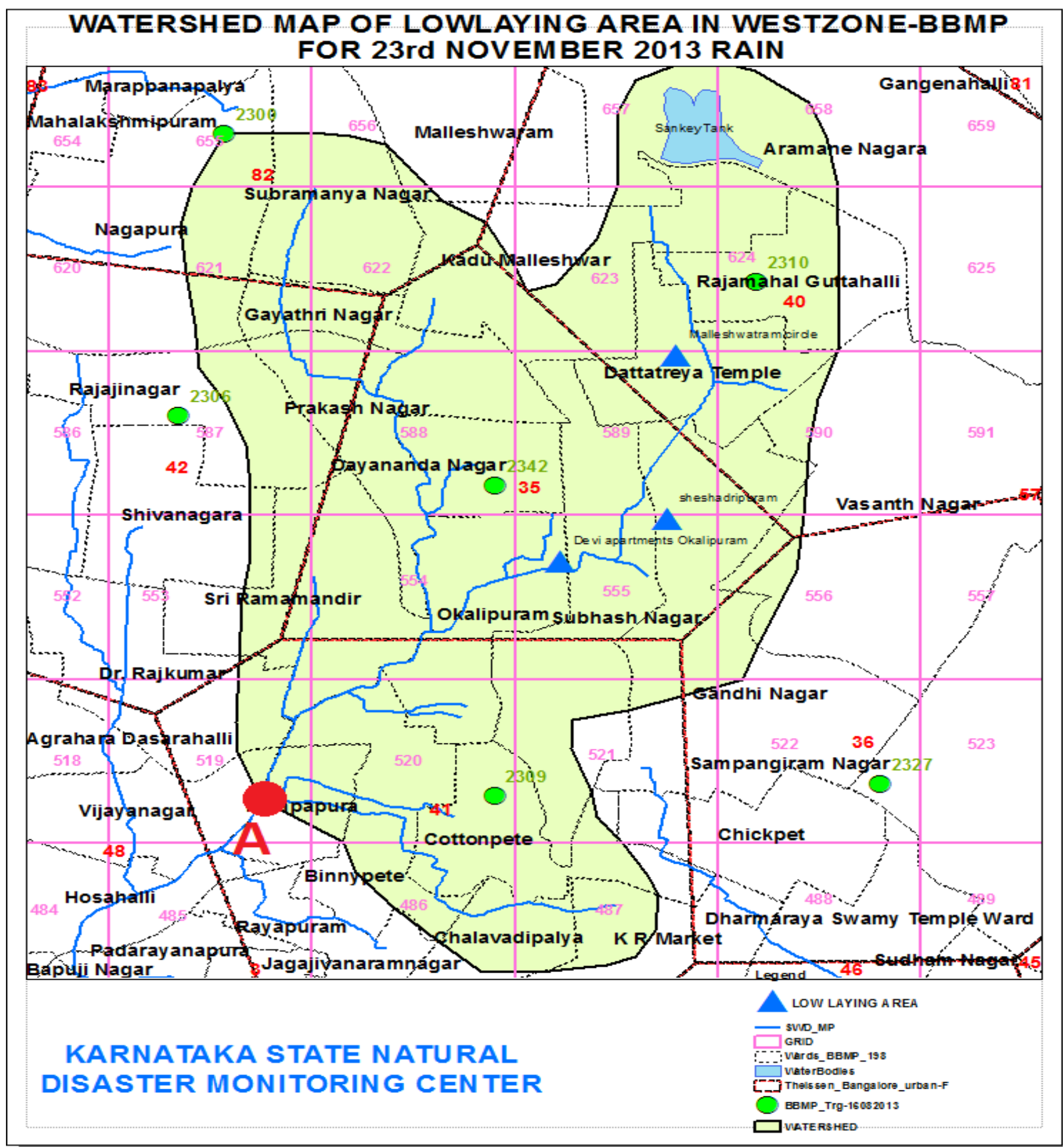

Fig-4: Low laying area in West Zone of Bangalore BBMP area

The analysis reveals that the excess runoff is due to less carrying capacity of the storm water drains in the area. Due to urban developments on wetlands and open spaces, the paved area has been increased. It has causes less infiltration and more runoff volume.

The impact of urban flooding is directly on the daily living of the people. The inundated residential layouts make it tough for the people to live. The inundation of roads makes it difficult for the public transport. Many trees will be uprooted and it will be difficult for the authorities to clear the debris of the high rain events. Due to fall of electric poles BESCOM will suffer crores of rupees loss. Uprooted trees and electric poles have damaged the vehicles parked in the vicinity. 
The ill effects of urban flooding in low laying areas hinder the development of that area. The economy of the land declines due to under developments. Overall, the socio economic decline will be resulted as an impact of urban flooding.

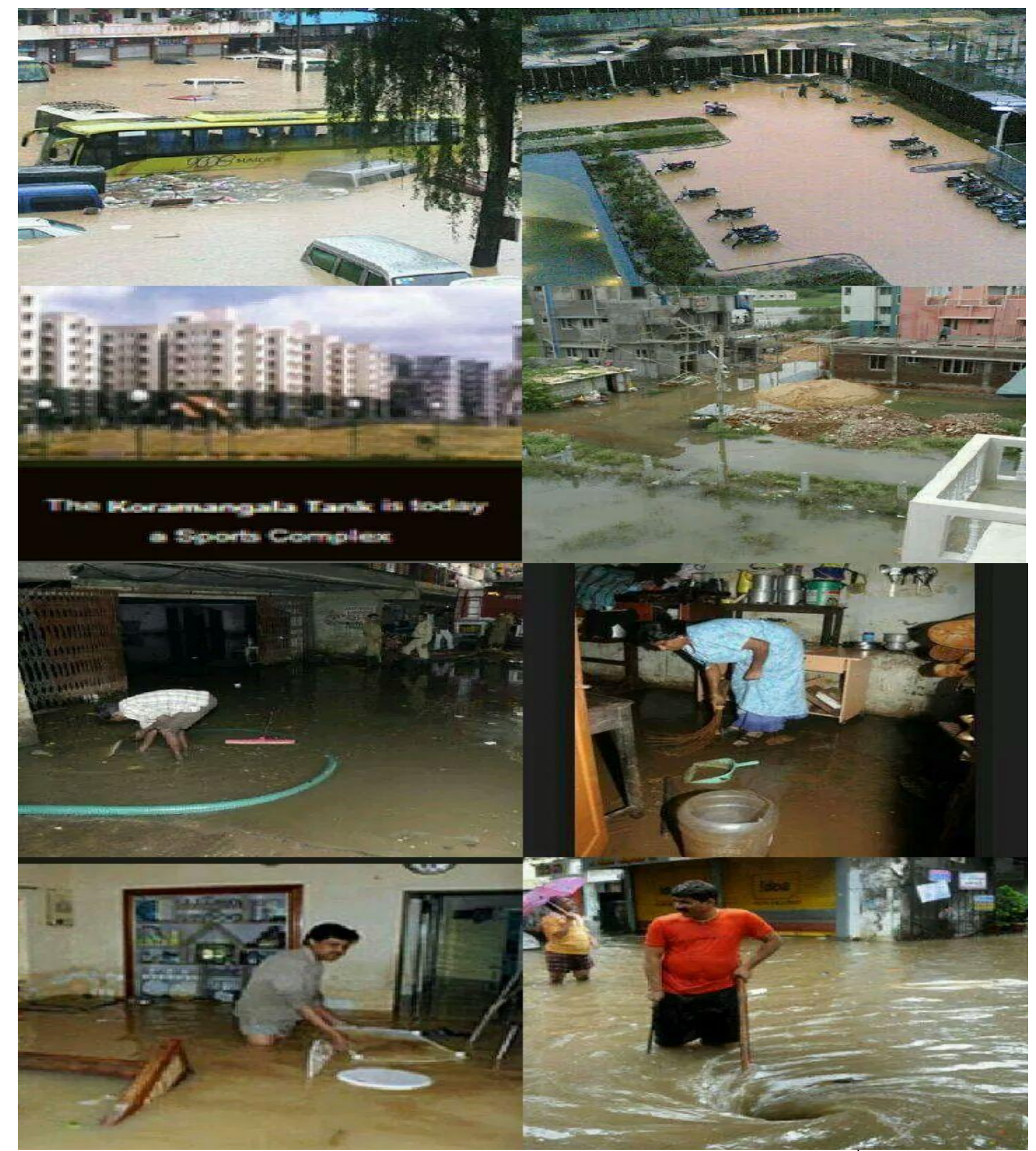

Fig-5 Koramangala tank today \& effect of urbanization in Bangalore, flooded residential areas $-23^{\text {rd }}$ November 2013 rain (Courtesy: TOI) 

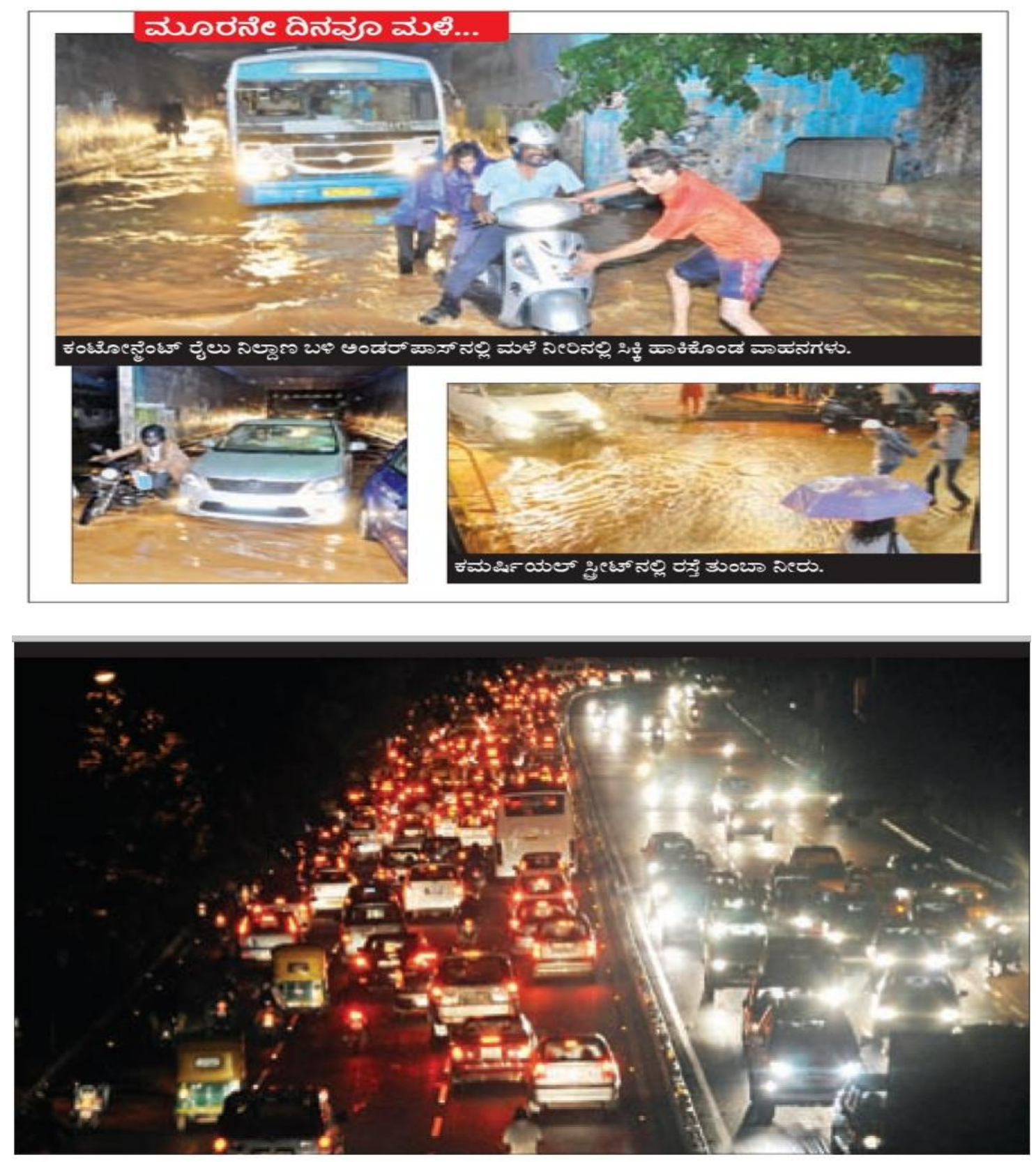

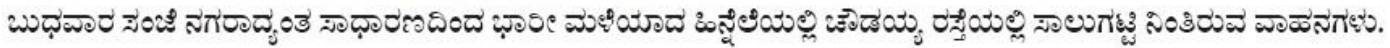

Fig-6 Heavy rain in Bangalore- Urban flood affects on 23 ${ }^{\text {rd }}$ November 2013 (Courtesy: TOI) (Reference -3)

The above Fig-5 \& Fig-6 shows the flood related disaster in Bangalore city.

\section{REFERENCES:}

[1] India Meteorological Department, NOAA (19711990))

[2] Ramachandra T. V. and Pradeep P. Mujumdar, 2009, Urban Floods: Case Study of Bangalore, Journal of the National Institute of Disaster Management, Vol. 3, No. 2, April 2009, pp. 1-98.

[3] Time of India articles 